\title{
Preventing Healthcare-Associated Legionellosis with Rapid Reduction of High Concentrations of Legionella Using Mechanical Removal of Blind Ends and Intensive Hot Water Flushing
}

\author{
Sprječavanje legioneloza povezanih sa zdravstvenim sustavom brzim smanjenjem visoke \\ koncentracije legionela uz pomoć mehaničkog uklanjanja slijepih završetaka i ispiranjem \\ vrućom vodom \\ Alan Medić ${ }^{1}$, Anamarija Jurčev-Savičević2 ${ }^{2}$ Boris Dželalija ${ }^{3,4}$, Dinko Puntaric ${ }^{5}$, Ines Leto ${ }^{3,4}$, Ivanka Matas ${ }^{6}$, Ljilja Balorda \\ ${ }^{1}$ Department of Epidemiology, Zadar Institute of Public Health, 23000 Zadar, Croatia \\ ${ }^{2}$ Teaching Public Health Institute of Split and Dalmatia County, 21000 Split, Croatia; University Department of Health Studies, University of Split, 21000 Split, Croatia \\ ${ }^{3}$ Department of Health Studies, University of Zadar, 23000 Zadar, Croatia \\ ${ }^{4}$ Department of Infectious Diseases, Zadar General Hospital, 23000 Zadar, Croatia \\ ${ }^{5}$ Zagreb Institute of Public Health, 10000 Zagreb, Croatia \\ ${ }^{6}$ Department of Microbiology and Parasitology, Zadar Institute of Public Health, 23000 Zadar, Croatia \\ ${ }^{7}$ Department of Public Health, Zadar Institute of Public Health, 23000 Zadar, Croatia
}

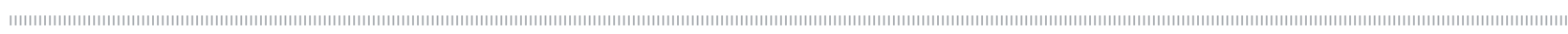

Keywords:

prevention

Legionella pneumophila

hospital

water flow

Ključne riječi:

prevencija

Legionella pneumophila

bolnica

protok vode

Primljeno: 08-09-2020

Received: 08-09-2020

Prihvaćeno: 09-10-2020

Accepted: 09-10-2020

$\triangle$ Corresponding author: Assist. Prof. Alan Medić, MD, PhD Department of Epidemiology, Zadar Institute of Public Health, Ljudevita Posavskog 7, HR-23000 Zadar, Croatia E-mail: alan.medic@ziz.htnet.hr; Tel.. +385-23-300841; Fax.: +385-23-300844

\begin{abstract}
Background: The aim of this paper was to present the effectiveness of the mechanical removal of blind ends and flushing of hot water systems at outlets as the only possible emergency measures to reduce the concentration of Legionella spp in hot water.

Methods: Two measures have been undertaken: mechanical removal of blind ends and intensive hot water flushing when the water has not been used for more than 7 days.

Results: We detected Legionella pneumophila serogroup 1 in concentration of 1.000- 55.000 CFU/L at all samples sites. In the control sampling, after three weeks, we found seven sampling sites negative for Legionella and only two sampling sites positive. All nine sampling sites were negative after ten weeks.

Conclusion: Establishing good water flow throughout the hospital seems to be the most important measure, in order to make the multiplication of Legionella in the hot water distribution systems unlikely.
\end{abstract}

Introduction

This paper describes the contamination of the hot water system by Legionella bacteria at the Zadar General Hospital (Zadar GH) and the success of emergency measures to reduce their concentration in hospital hot water. The aim of this paper is to present the effectiveness of the mechanical removal of blind ends and flushing of hot water systems at outlets as the only possible emergency measures to reduce the concentration of Legionella spp in hot water. 


\section{Material and Methods}

This paper describes the contamination of the hot water system by the Legionella spp at the Zadar GH and the success of emergency measures to reduce their concentration in hospital hot water. Only two measures have been undertaken: mechanical removal of blind ends and intensive hot water flushing when the water has not been used for more than seven days. The mechanical removal of the blind ends was carried out in all places where flushing could not be performed due to the inability to access the outlet pipe or the installation of faucets. In places where water had not been used for more than seven days, but were easily accessible or where faucets could be installed, tap water was discharged at least once a week for 1 to 2 minutes. The Zadar GH Drawing according to the department sampling sites is shown in Figure 1.

Figure 1. Zadar General Hospital Drawing according to the Departments and sampling Sites

Slika 1. Skica OpĆE Bolnice Zadar s označEnim odjelima i mJestima uZorkovanja

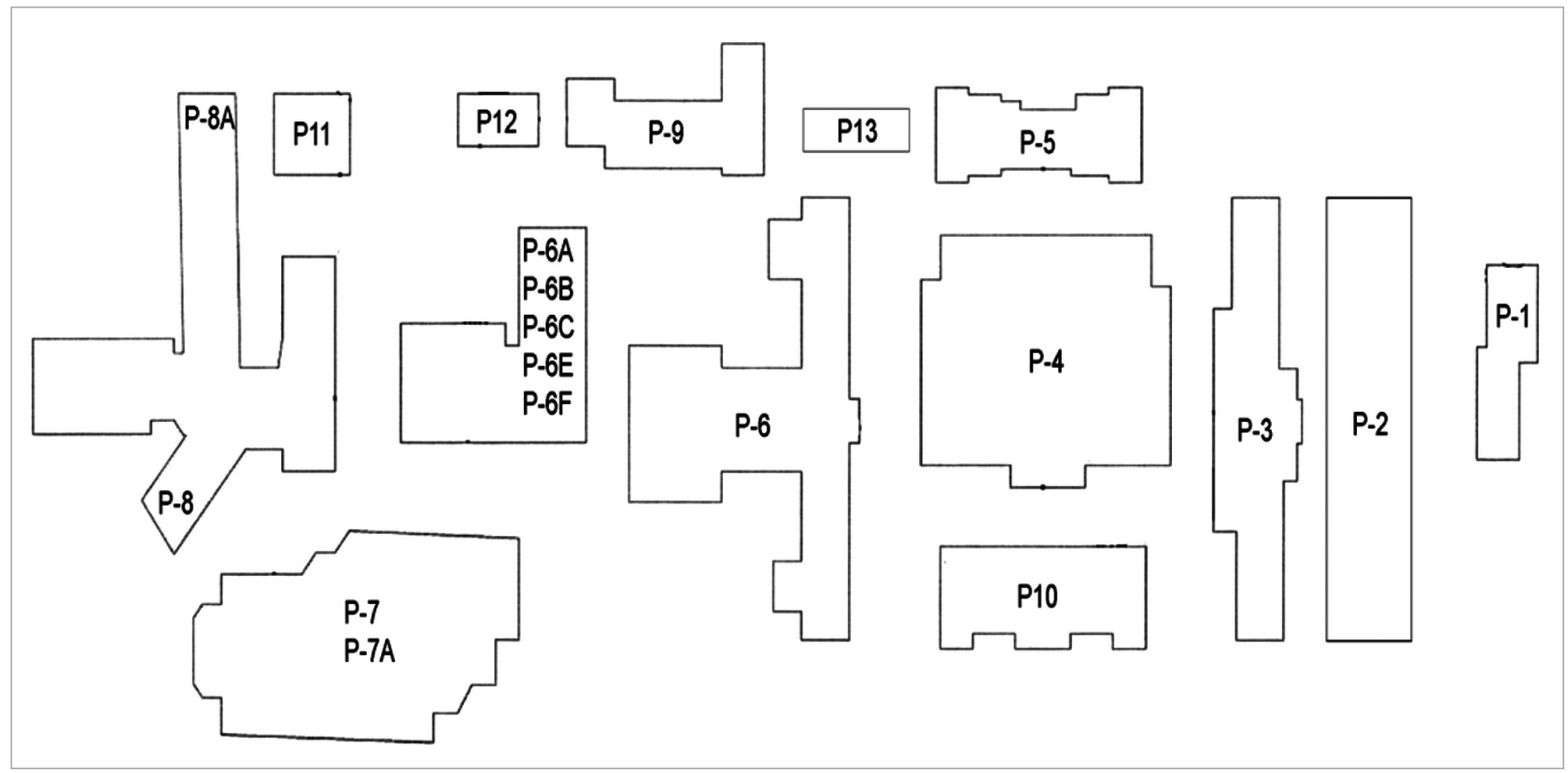

Legend/Legenda: P1- Pathology and Forensic Medicine/Patologija i forenzička medicina, P2- Hospital Kitchen/Bolnička kuhinja, P3- Outpatient Clinics/Poliklinika, P4- Internal Medicine, Emergency Hospital Admission/Interna medicina, Hitni bolnički prijem, P5- Infectology/Infektologija, P6 (A,B, C, E, F) - Surgery, Anesthesiology, Central Sterilization, Hemodialysis, Neurology, Psychiatry/Kirurgija, Anesteziologija, Centralna sterilizacija, Hemodijaliza, Neurologija, Psihijatrija, P7 A-Ophthalmology, Cytology/Oftalmologija, Citologija, P7- Pediatrics, Pulmonology/Pedijatrija, Pulmologija, P8- Neonatology/Neonatologija, P8 A- Gynecology and Obstetrics, Transfusion Medicine/Ginekologija i opstetricija, Transfuzijska medicina, P9- Urology, Otolaryngology/Urologija, Otolaringologija, P10- Administrative building/Upravna zgrada, P11- Pharmacy/Ljekarna, P12- Electric station/Električna stanica, P13- Boiler room/Kotlovnica

Sampling was carried out using sample collection standard procedures, transport and storage according to ISO standards. Cultivation and identification were performed by the cultural method according to ISO standards. The concentration of the bacteria was determined with membrane filtration using paper filter of $0.20 \mu \mathrm{m}$ pore size (a polyamide filter, Millipore, Bedford, USA).

Colonies grown on BCYE agar with cysteine were further tested for Legionella pneumophila serogroup 1, serogroup 2-14 and Legionella non-pneumophila by the use of the agglutination test (Legionella Latex Test, Oxoid ${ }^{[6-7]}$.

\section{Results}

During a routine epidemiological survey, the Hospital Infections Control Team at the Zadar GH noticed that the hot water temperature was not satisfactory (it was from 30 to $35^{\circ} \mathrm{C}$ ). Hot water sampling was taken at nine locations and resulted with the detection of Lp. serogroup 1 in concentrations of 3.000-55.000 cfu/l (colony-forming unit). (Table 1) 
Table 1. Legionella pneumophila serogroup 1. CONCEntration in Zadar General Hospital hot water before and after EMERGENCY MEASURES

Tablica 1. Koncentracija Legionella pNeumophila serogroupe 1 u vrućoj vodi OpĆe bolnice Zadar Prije i NaKon primJENE HITNIH MJERA

\begin{tabular}{|c|c|c|c|c|c|}
\hline \multirow{4}{*}{$\begin{array}{l}\text { Site } \\
\text { code }\end{array}$} & \multirow{4}{*}{ Sampling site } & \multicolumn{4}{|c|}{ Measures taken } \\
\hline & & $\begin{array}{l}\text { a) Routine surveil- } \\
\text { lance-low hot water } \\
\text { temperature detected } \\
\text { (October 10th) }\end{array}$ & $\begin{array}{l}\text { c) Removal of blind } \\
\text { ends and intensive } \\
\text { flushing } \\
\text { (November 15th) } \\
\end{array}$ & $\begin{array}{l}\text { e) Additional removal } \\
\text { of blind ends and } \\
\text { intensive flushing } \\
\text { (December 20th) }\end{array}$ & $\begin{array}{l}\text { g) Additional removal } \\
\text { of blind ends and } \\
\text { intensive flushing } \\
\text { (February 2nd) }\end{array}$ \\
\hline & & \multicolumn{4}{|c|}{ Sampling results: Legionella pneumophila serogroup $1(c f u / l)^{*}$} \\
\hline & & b) The first sampling & d) The second sampling & f) The third sampling & h) The fourth sampling \\
\hline $\mathrm{P} 2$ & Kitchen & 13.000 & 0 & 0 & 0 \\
\hline P4 & $\begin{array}{l}\text { Endocrinology Unit - } \\
\text { Department of Internal } \\
\text { Medicine }\end{array}$ & 21.000 & 0 & 0 & 0 \\
\hline P5 & Department of Infectology & 4.000 & 0 & 0 & 0 \\
\hline P6 & $\begin{array}{l}\text { Abdominal Surgery Unit- } \\
\text { Surgery Department }\end{array}$ & 3.000 & 0 & 0 & 0 \\
\hline P6A & $\begin{array}{l}\text { Intensive Care Unit- } \\
\text { Department of Anesthesiology, } \\
\text { Reanimatology and Intensive } \\
\text { Medicine }\end{array}$ & 21.000 & 3.000 & 0 & 0 \\
\hline P6B & Department of Neurology & 50.000 & 0 & 0 & 0 \\
\hline P7 & Department of Pediatrics & 26.000 & 1.000 & 0 & 0 \\
\hline P8 & $\begin{array}{l}\text { Neonatology Unit- } \\
\text { Departments of Gynecology } \\
\text { and Obstetrics }\end{array}$ & 55.000 & 0 & 10.000 & 0 \\
\hline $\mathrm{P} 13$ & Boiler room & 1.000 & 0 & 0 & 0 \\
\hline
\end{tabular}

${ }^{\star}$ Legend. cfu/l (colony-forming unit)

\section{Measures taken after sampling:}

\section{A. Immediate measures taken}

- Cleaning of shower rosette and taps

- Daily drainage of water for 1-2 minutes at locations that have not been used for at least seven days during the first week,

- The hospital infection control team with its technical service staff located, marked and mechanically removed the blind spots. A total of 54 blind ends (valves in the wall that cannot be drained) and 47 locations where water had not been used for more than seven days were detected

B. Measures not taken due to the age/construction issues of the hospital water distribution system:

- Thermal disinfection of hot water due to the deterioration of the heating system, i.e. the technical inability to raise the temperature in boilers above $65^{\circ} \mathrm{C}$.

- Chemical disinfection (use of chlorine preparations) and the installation of chlorinators in the hot water system due to the no scheme of the wa- ter supply network and no possibility to control distribution of chlorine in the hot water system

Control sampling after one month resulted with two positive samples out of a total of nine samples (locations) at places where the prescribed anti-epidemic measures were not regularly implemented (water discharge at sites not used for more than a week). Following corrective measures, these deficiencies were corrected and negative results were obtained in all samples three months later. Microbiological findings of water were within normal limits, free residual chlorine was $0.35 \mathrm{mg} / \mathrm{L}$.

\section{Discussion}

The present article outlines our experience of Legionella control in heavily contaminated hospital water in circumstances where usual disinfection methods (pasteurization or hyperclorination) were not possible due to the old and large water network.

Proctor et al. found that the temperature was more important than both pipe composition and the concentration of assimilable organic carbon for con- 
trolling L pneumophilla growth, and that high temperatures decreased the effect of copper pipes ${ }^{\left[{ }^{[8]}\right.}$.

Cervero-Aragó et al. found that amoebae-associated Legionella decreased Legionella inactivation by chlorine and high temperature. They concluded that water close to the tap posed an increased health risk given the lower chlorine levels and temperatures ${ }^{[9]}$.

The hot water heater outlet temperature should be at or above $60^{\circ} \mathrm{C}$; the hot water temperature at the coldest point in the hot water heater, storage tank, or distribution system should be at or above $51^{\circ} \mathrm{C}$; and the cold water temperature in any part of the system should be at or below $25^{\circ} \mathrm{C}$. If the hazard analysis and critical control point team determine that these temperatures cannot be achieved, it may then be concluded that additional hazard control measures are required $^{[10]}$. In the Zadar $\mathrm{GH}$, hot water temperature ranged from $25-44^{\circ} \mathrm{C}$. Due to the technical issues related to the old construction and complex water distribution system with undocumented reconstruction during hospital history, it was not possible to perform thermal shock disinfection $\left(>65^{\circ} \mathrm{C}\right)$, nor even maintain the daily temperature at the outlet above $50^{\circ} \mathrm{C}$.

In Europe, thermal treatment is recommended. $\mathrm{Al}$ ternative treatments are only permitted when thermal treatment is insufficient. Alternative treatments are recommended in the following order: (1) physical disinfection (pasteurization, ultraviolet radiation, micro and ultrafiltration); (2) electrochemical disinfection (copper-silver ionization, anodic oxidation); and (3) chemical disinfection (free chlorine, chlorine dioxide, etc. ${ }^{[11]}$.

Permanent installation of a chlorinator and hyperchlorination in the water distribution system of the Zadar GH was not possible. The concentrations of chlorine in the water could not be controlled since there were no technical drawings of a water supply network. Most of the facilities at Zadar GH were built between 1887 and 1978 (9 out of 14), while the rest were renovated from 2000 to 2006 . Over the years, the hospital has undergone numerous repairs in terms of the reconstruction and upgrading of many rooms, as well as the extension of water pipes to the existing ones. In addition, chlorination has many disadvantages, including the fact that $4-6 \mathrm{mg} / \mathrm{L}$ of chlorine kills only $90 \%$ of Lp. species ${ }^{[12]}$.

Pasteurization and flushing are methods of first choice as preventive and antiepidemic measures because they do not require special equipment and can be implemented immediately. Therefore, we established a good flow of hot water and reduced water stagnation.

In the management of these anti-epidemic measures, very little knowledge of hospital staff (medical and technical) about Legionella was shown, which significantly reduced the speed of implementation of measures and their effectiveness. Danila et al. surveyed Minnesota hospitals and found that only 51\% of the respondents knew about the ASHRAE standard, $27 \%$ had water management plans, and $21 \%$ regularly tested water for Legionella ${ }^{[13]}$. Acquiring knowledge in this area is necessary for a better implementation of anti-epidemic measures.

Our experience may be of value for facilities that have a large plumbing network and inability to raise the hot water temperature sufficiently and do not allow other measures to control LD such as hyperchlorination. As suggested by the WHO, all healthcare facilities should have a specific water safety plan (WSP) as part of their infection control program. Therefore, we improved WSP in Zadar GH, which provides a systematic assessment and prioritization of hazards, as well as operational monitoring of barriers and control measures. This plan has addressed issues such as training of medical and nonmedical staff in an active participation to the WSP implementation task.

The limitation of the study is in fewer samples and a lower monitoring frequency (once a month) than recommended due to financial reasons. More frequent sampling could give a better insight into the dynamics of legionella concentrations in the water supply system.

\section{Conclusion}

In this hospital, the mechanical removal of the blind ends and regular flushing of hot water were the only possible measures to reduce the concentration of legionella in the plumbing hospital system. Establishing good water flow throughout the hospital water supply system seems to be the most important measure, in order to make the multiplication of the bacterium in hot water distribution systems unlikely.

\section{Funding}

The authors did not receive support from any organization for the submitted work.

\section{Conflict of Interest}

The authors have no relevant financial or non-financial interests to disclose.

\section{REFERENCES}

${ }^{[1]}$ Borella P, Bargellini A, Marchegiano P, Vecchi E, Marchesi I. Hospital-acquired Legionella infections: an update on the procedures for controlling environmental contamination. Ann Ig 2016;28(2):98-108.

${ }^{[2]}$ World Health Organization. Legionella and the prevention of legionellosis. Geneva, Switzerland: World Health Organization; 2007. Available from: http://www.who.int/water_sanitation_ health/emerging/legionella.pdf Accessed January 12, 2020. 
${ }^{[3]}$ Almeida D, Cristovam E, Caldeira D, et al. Are there effective interventions to prevent hospital-acquired Legionnaires' disease or to reduce environmental reservoirs of Legionella in hospitals? A systematic review. Am J Infect Control 2016;44:e183-8.

${ }^{[4]}$ Demirjian A, Lucas CE, Garrison LE, et al. The importance of clinical surveillance in detecting Legionnaires' disease outbreaks: a large outbreak in a hospital with a legionella disinfection system-Pennsylvania, 2011-2012. Clin Infect Dis 2015;60:1596-602.

${ }^{[5]}$ Beauté J; The European Legionnaires' Disease Surveillance Network. Legionnaires' disease in Europe, 2011 to 2015. Euro Surveill 2017;22(27):30566.

${ }^{[6]}$ Croatian Standards Institute. Water quality-Sampling for microbiological analysis. HRN EN ISO 19458. Croatian Standards Institute, Zagreb, 2008.

${ }^{[7]}$ Croatian Standards Institute. Water quality-Detection and enumeration of Legionella-Part 2: Direct membrane filtration method for waters with low bacterial counts. HRN EN ISO 11731-2. Croatian Standards Institute, Zagreb, 2008.

${ }^{[8]}$ Proctor CR, Dai D, Edwards MA, Pruden A. Interactive effects of temperature, organic carbon, and pipe material on micro- biota composition and Legionella pneumophila in hot water plumbing systems. Microbiome 2017; 5:130.

${ }^{[9]}$ Cervero-Aragó S, Rodríguez-Martínez S, Puertas-Bennasar A, Araujo RM. Effect of common drinking water disinfectants, chlorine and heat, on free Legionella and amoebae-associated Legionella. PLoS One 2015; 10:e0134726.

${ }^{[10]}$ BSR/ASHRAE Standard 188P. Proposed new standard 188: prevention of legionellosis associated with building water systems. Second public review. Available from: https://essentialwatertech.com/pdfs/Std-188P-PPR2-Final-6-10-2011.pdf Accessed January 12, 2020.

${ }^{[11]}$ Kenhove Van E, Dinne K, Janssens A, Laverge J. Overview and comparison of Legionella regulations worldwide. Am J Infect Control 2019; 47(8): 968-978.

${ }^{[12]}$ La Mura S, Joppolo CM, Pitera LA, Angermann JP, Izard M. Legionellosis prevention in building water and HVAC systems: a practical guide for design, operation and maintenance to minimize the risk. Brussels (Belgium): Federation of European Heating, Ventilation and Air Conditioning Associations; 2013.

${ }^{[13]}$ Danila RN, Koranteng N, Como-Sabetti KJ, et al. Hospital Water Management Programs for Legionella Prevention, Minnesota, 2017. Infect Control Hosp Epidemiol 2018; 39:336-8. 